\title{
XAF1 expression and regulatory effects of somatostatin on XAF1 in prostate cancer cells
}

\author{
Zhaoquan Xing ${ }^{1 \dagger}$, Zunlin Zhou ${ }^{2 \dagger}$, Rong $\mathrm{Yu}^{3,4}$, Shuling $\mathrm{Li}^{1 *}$, Chunde $\mathrm{Li}^{4}$, Sten Nilsson ${ }^{4}$, Zhaoxu Liu $2,3^{*}$
}

\begin{abstract}
Background: Somatostatin prevents cell proliferation by inducing apoptosis. Downregulation of the XAF1 transcript may occur during the development of prostate cancer. It is interesting to evaluate the potential regulatory effects of somatostatin on XAF1 expression during the development of prostate cancer cells.

Methods: XAF1 mRNA and protein expression in human prostate epithelial cells RWPE-1, androgen dependent prostate cancer LNCaP, and androgen independent DU145 and PC3 cells were evaluated using RT-PCR and Western blot. The regulation of XAF1 mRNA and protein expression by somatostatin and its analogue Octreotide was evaluated.
\end{abstract}

Results: Substantial levels of XAF1 mRNA and proteins were detected in RWPE-1 cells, whereas prostate cancer cells LNCaP, DU145 and PC3 exhibited lower XAF1 expression. Somatostatin and Octreotide up-regulated XAF1 $\mathrm{mRNA}$ and protein expression in all prostate cancer cell lines.

Conclusions: XAF1 down-regulation may contribute to the prostate cancer development. The enhanced XAF1 expression by somatostatin indicates a promising strategy for prostate cancer therapy.

\section{Background}

Prostate cancer is the most common cancer and the leading cause of cancer death among men in the United States and Europe $[1,2]$. It was estimated that approximately 186,320 new cases and 28,660 prostate cancerrelated deaths occurred in the US in 2008 [1]. Although epidemiological studies showed that the incidence of prostate cancer in Asians is much lower than that in African-Americans [3], the occurrence of the disease has rapidly increasing in China[4]. Most prostate cancers are initially androgen-dependent but become androgenindependent and refractory to hormone withdrawal therapy [5]. Like all other human malignancies, prostate cancer cells escape apoptotic death through highly efficient pathways involving multiple mechanisms [6,7].

$\mathrm{X}$-linked inhibitor of apoptosis protein-associated factor-1 (XAF1) was first identified as an interacting protein of X-linked inhibitor of apoptosis (XIAP) [8]. XIAP

\footnotetext{
* Correspondence: qilulishuling@163.com; zhaoxv|@sdu.edu.cn

+ Contributed equally

'Department of Integrated Traditional Chinese and Western Medicine, Qilu

Hospital, Shandong University, Jinan, 250012 P.R. China

${ }^{2}$ Department of Urology, Qilu Hospital, Shandong University, Jinan, 250012

P.R. China

Full list of author information is available at the end of the article
}

suppresses apoptotic cell death by binding to caspases and inhibiting their functions. XAF1 antagonizes XIAP activities, thereby promoting apoptosis [9]. XAF1 can dramatically sensitize cancer cells to apoptotic triggers such as TRAIL, etoposide treatments 5-fluorouracil [10], $\mathrm{H}_{2} \mathrm{O}_{2}$, c-irradiation, ultraviolet [11], and tumour necrosis factor $-\alpha$, which are independent of its interaction with XIAP [12]. XAF1 is therefore believed to play an important role in the major apoptosis-related pathways. $X A F 1$ also serves as a candidate tumour suppressor gene. Loss of XAF1 has been observed in a variety of cancer cell lines and human cancers [13-16]. However, little is yet known about its potential implication in prostate cancer.

So far, there have been no effective therapeutic measures for the treatment of hormone refractory prostate cancer. Treatment with somatostatin may therefore be a possible therapeutic alternative to chemotherapy in hormone refractory prostate cancer patients. Somatostatin, originally identified as a neuropeptide inhibiting growth hormone release more than 30 years ago, is widely present in central and peripheral human cells/tissues including prostate. Somatostatin has been shown to exert a potent anti-tumour action by affecting tumour

\section{() Biomed Central}


cell proliferation, apoptosis, angiogenesis and the host's immune response [17-21]. Octreotide is an analogue of somatostatin and has been used in clinical practice since data emerged in the $1980 \mathrm{~s}$ confirming its ability to palliate carcinoid syndrome [22]. Our previous results have shown that somatostatin may affect the mitochondria of LNCaP and DU145 cells in a way that eventually triggers mitochondrial-mediated apoptosis and exert its effects on prostate cancer cells via MAPK pathway and by regulating the activities of phosphotyrosine phosphatases [23].

In the current study, we examined XAF1 mRNA and protein expression in four cell lines, and determined regulatory effects of somatostatin and Octreotide on $X A F 1$ expression in prostate cancer cell lines. We found that somatostatin and Octreotide up-regulated XAF1 mRNA and protein expression in prostate cancer cell lines. The enhanced XAF1 expression by somatostatin indicates a promising strategy for prostate cancer therapy.

\section{Materials and methods}

\section{Cell lines and cell culture}

A human prostate epithelial cell line (RWPE-1) and prostate cancer cell lines (LNCaP, DU145 and PC3) were used and were obtained from the American Type Culture Collection (ATCC). LNCaP, DU145 and PC3 were maintained in RPMI-1640 medium supplemented with $10 \%$ foetal bovine serum (FBS). RWPE-1 cells were maintained in complete keratinocyte serum-free medium (K-SFM) containing $50 \mu \mathrm{g} / \mathrm{ml}$ bovine pituitary extract and $5 \mathrm{ng} / \mathrm{ml}$ epidermal growth factor. The cultures were maintained in a humidified $5 \% \mathrm{CO}_{2}$ environment at $37^{\circ}$ $\mathrm{C}$. The medium was changed twice a week and the cells were trypsinized and subcultivated once a week. Somatostatin and Octreotide (Sigma) were prepared as described previously [24]. The cells were treated with 1 $\mathrm{nM}$ somatostatin and $1 \mathrm{nM}$ Octreotide for different periods of time $(0,1 \mathrm{~h}, 12 \mathrm{~h}, 24 \mathrm{~h}, 72 \mathrm{~h})$, as described by Brevini [25]. Controls were untreated cells.

\section{RNA extraction and RT-PCR}

XAF1 mRNA was detected using reverse transcription PCR (RT-PCR). Total cellular RNA was extracted using Trizol reagent (Invitrogen, Carlsbad, CA), according to the manufactures' instruction. cDNA was synthesized using random primers (N6) and M-MLV reverse transcriptase. PCR was performed by using XAF1-specific primers as follows: forward: 5'-ATG GAA GGA GAC TTC TCG GT-3'; reverse: 5'-TTG CTG AGC TGC ATG TCC AG-3' and the conditions were: denaturation at $94^{\circ} \mathrm{C}$ for $5 \mathrm{~min}$, followed by 34 cycles of $94^{\circ} \mathrm{C} 30 \mathrm{~s}$, $60^{\circ} \mathrm{C} 30 \mathrm{~s}, 72^{\circ} \mathrm{C} 45 \mathrm{~s}$, and then a final cycle of $10 \mathrm{~min}$ at $72^{\circ} \mathrm{C}$. Amplification products $(290 \mathrm{bps})$ were electrophoresed onto 1.5\% agarose gels and visualized by $0.5 \%$ ethidium bromide staining. The results of electrophoresis were analyzed by the Gel Image System Fluor Chem TM 9900 (Alpha Innotech).

\section{Western blot analysis}

Cells were lysed in buffer containing $50 \mathrm{mM}$ Tris- $\mathrm{HCl}$ (pH 7.5), $250 \mathrm{mM} \mathrm{NaCl}, 0.1 \% \mathrm{NP}-40$ and $5 \mathrm{mM}$ EGTA, $50 \mathrm{mM}$ sodium flu-oride, $60 \mathrm{mM} \beta$-glycerol-phosphate, $0.5 \mathrm{mM}$ sodium-vanadate, $0.1 \mathrm{mM}$ PMSF, $10 \mu \mathrm{g} / \mathrm{ml}$ aprotinin and $10 \mu \mathrm{g} / \mathrm{ml}$ leupeptin. Protein concentration was determined using the BCA protein assay kit (Pierce Bio-technology, Inc., USA). Protein samples $(40 \mu \mathrm{g})$ were subjected to a $10 \%$ SDS-PAGE and electrophoretically transferred to PVDF membranes (Bio-Rad, Hercules, CA, USA). The membranes were first incubated with $5 \%$ nonfat milk in Tris-buffered saline (TBS). After washing three times in $0.1 \%$ Tween 20-TBS (TBST), the membranes were incubated with primary antibody (goat anti-human XAF1, 1:600; Santa Cruz Biotecnology) and $\beta$-actin (rabbit anti-actin antibody R-22, 1:1000; Santa Cruz Biotecnology) separately at $4^{\circ} \mathrm{C}$ overnight, followed with the corresponding secondary antibodies separately (1:2500) for $1.5 \mathrm{~h}$ at room temperature and the antibody-bound proteins were detected by the ECL system (Amersham Biosciences, Little Chalfont Buckinghamshire, UK).

\section{Results}

\section{Expression of XAF1 mRNA and protein in prostate cell} lines

The expression of XAF1 was detected at mRNA and protein levels with RT-PCR and Western blot. As shown in Figure 1, RT-PCR using cDNA primers specific for a segment of the human XAF1 mRNA provided a product of the expected size in four prostate cell lines. It showed lower expression of XAF1 mRNA in prostate cancer cells LNCaP, DU145 and PC3 compared with that in RWPE-1 cells which displayed the strongest expression of XAF1 mRNA among all four cell lines. We found protein expression of $X A F 1$ in these same cell lines by Western blot analysis, consistent with XAF1 mRNA expression. (Figure 1).

\section{Up-regulation of XAF1 mRNA and protein by somatostatin and Octreotide in prostate cancer cell lines}

To examine the regulatory effects of somatostatin and Octreotide on XAF1 mRNA and protein expression, prostate cancer cell lines (LNCaP, DU145 and PC3) were stimulated with $1 \mathrm{nM}$ somatostatin and $1 \mathrm{nM}$ Octreotide for different periods of time. We found a time-dependent manner of up-regulation of XAF1 mRNA and protein in the cells treated with somatostatin and Octreotide (Figure 2, 3 and 4). 


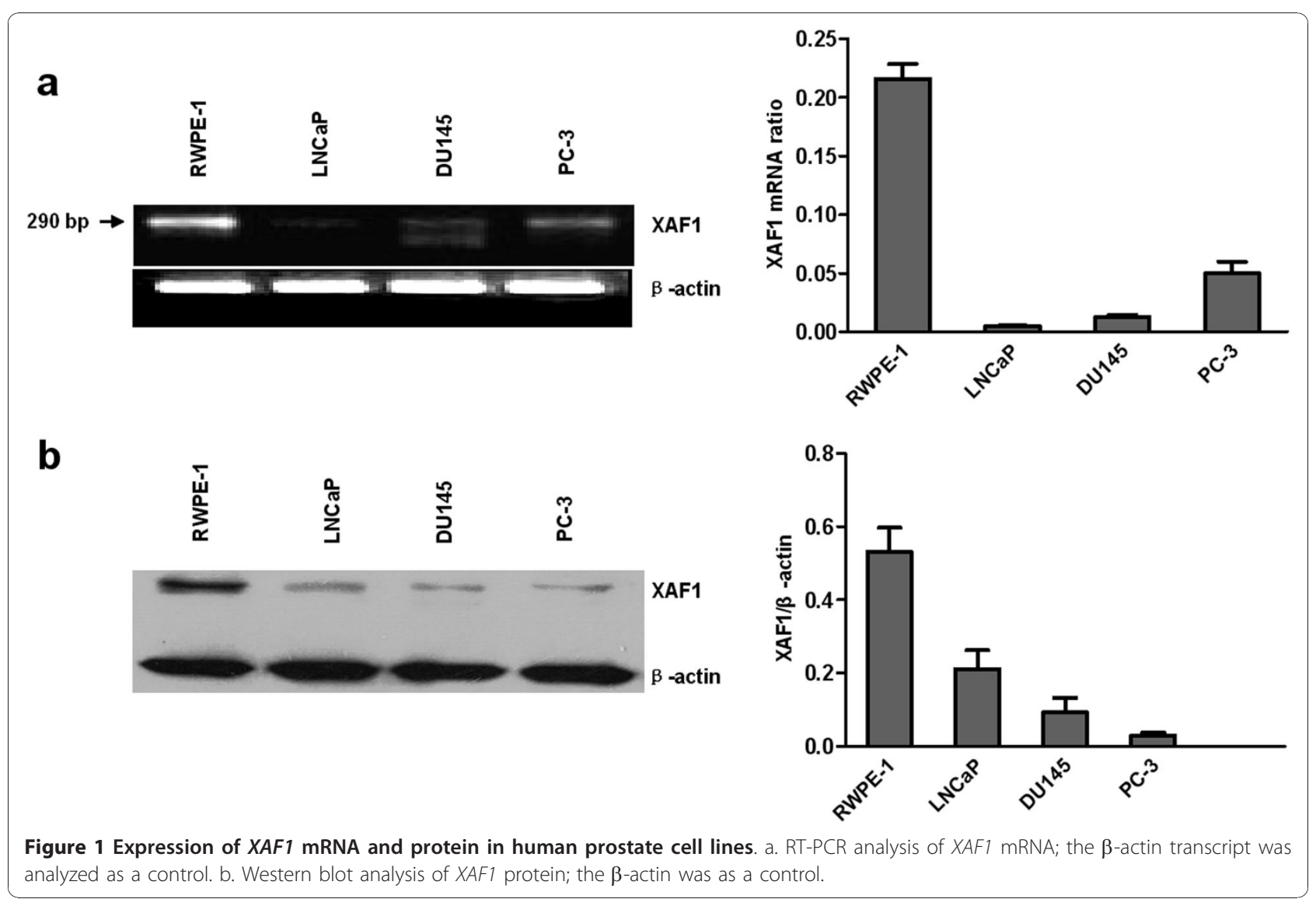

\section{Discussion}

Most prostate tumours are initially androgen-dependent but become androgen-independent and eventually refractory to the hormone [5]. There are many regulative factors among its progression, relapse and tumour outgrowth. Prostate cancer cells evade apoptotic cell death by a variety of mechanisms [6,7]. XAF1, a potent apoptosis-inducer [8], plays a significant role in the process. A number of studies have shown that XAF1 can sensitize cancer cells to TRAIL, TNF- $\alpha$, Fas, IFN- $\beta$ and MEK inhibitor-induced apoptosis in vitro [12,26-29]. Moreover, some researchers have recently indicated the effect of XAF1 combination with these factors on inhibition of tumour growth in vivo and demonstrated that $X A F 1$ can hinder tumour progression and promote outright regression in combination with TRAIL [30]. XAF1 mRNA is expressed at low or undetectable levels in most cancer cell lines, and transcriptional down-regulation in tumour cells as opposed to corresponding normal tissues and has been shown to occur at different frequencies in gastric adenocarcinomas, colorectal cancer, urothelial carcinomas, malignant melanomas, clearcell renal cell carcinomas [8,13-16,31], non-small cell lung cancer, bladder cancer and B chronic lymphocytic leukemia $[15,32,33]$.
Human prostate epithelial cells (RWPE-1) and prostate cancer cells (LNCaP, DU145 and PC3), which exhibit different features of prostate cancer progression from early stages to androgen independent stages, could mimic the development of prostate cancer clinically. Understanding the regulating effects of XAF1 during the whole progression may help us find potential therapeutic strategies for prostate cancer patients. To our knowledge, little is yet known about the regulatory effects of $X A F 1$ in many different types of human cancers. Three prostate cancer cell lines LNCaP, DU145 and PC3 were well established in laboratory experiments. Their invasive characteristics were found to be different among the three cell lines: lower invasive ability of LNCaP, medium invasive ability for DU145 and a higher ability for PC3. The varying expression of XAF1 suggests a causal changing of androgen dependency and invasiveness in the development of prostate cancer.

The antiproliferative effect of somatostatin may result from increased apoptosis. In breast cancer cells MCF-7, the cytotoxic effect of somatostatin is dependent on SHP-1 and results from caspase 8 activation, cell acidification and mitochondrial dysfunction [34]. Apoptosis is induced by SSTR3 as a result of the induction of $p 53$ and Bax [35] and is also induced by SSTR2 in HL-60 


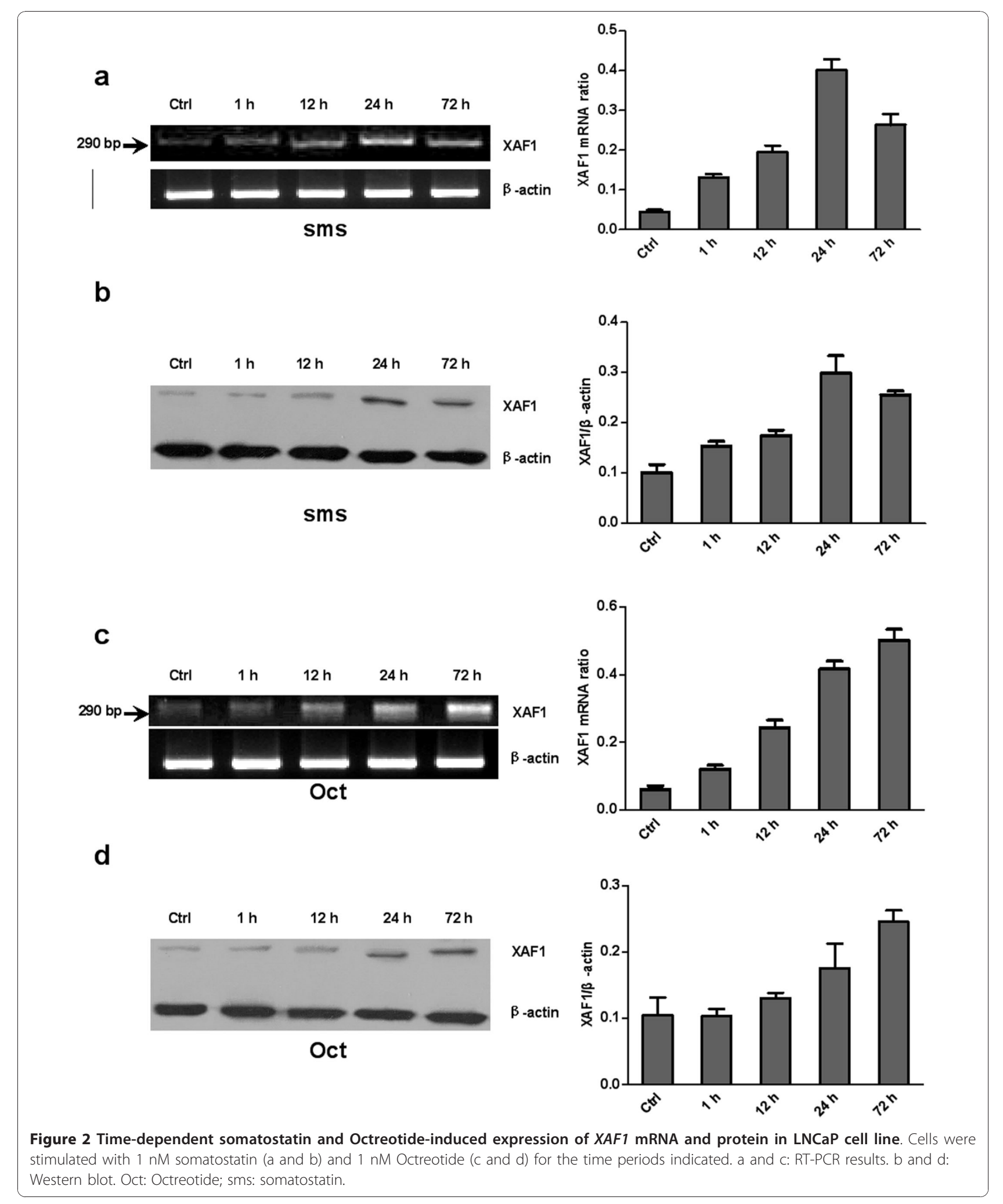




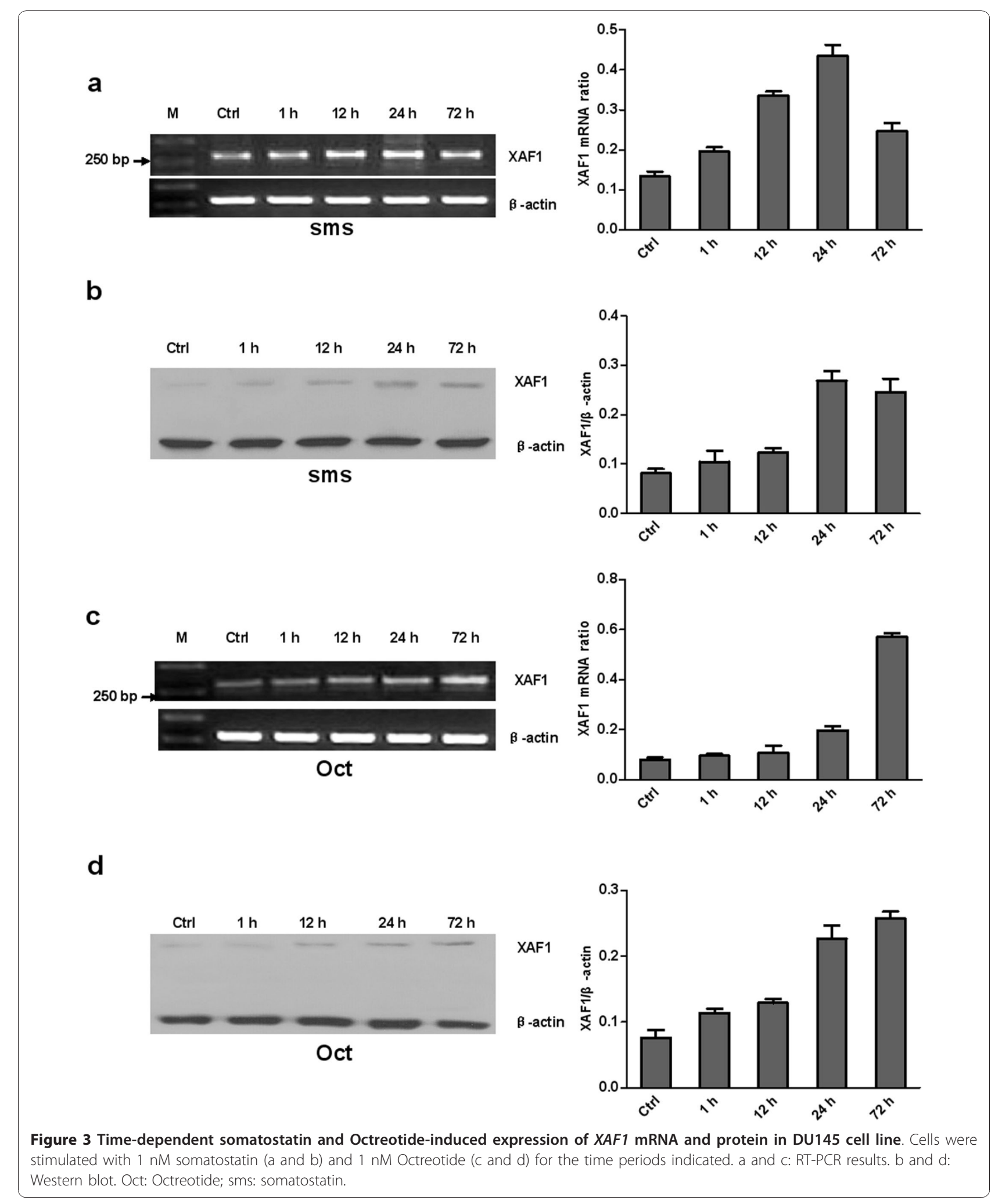




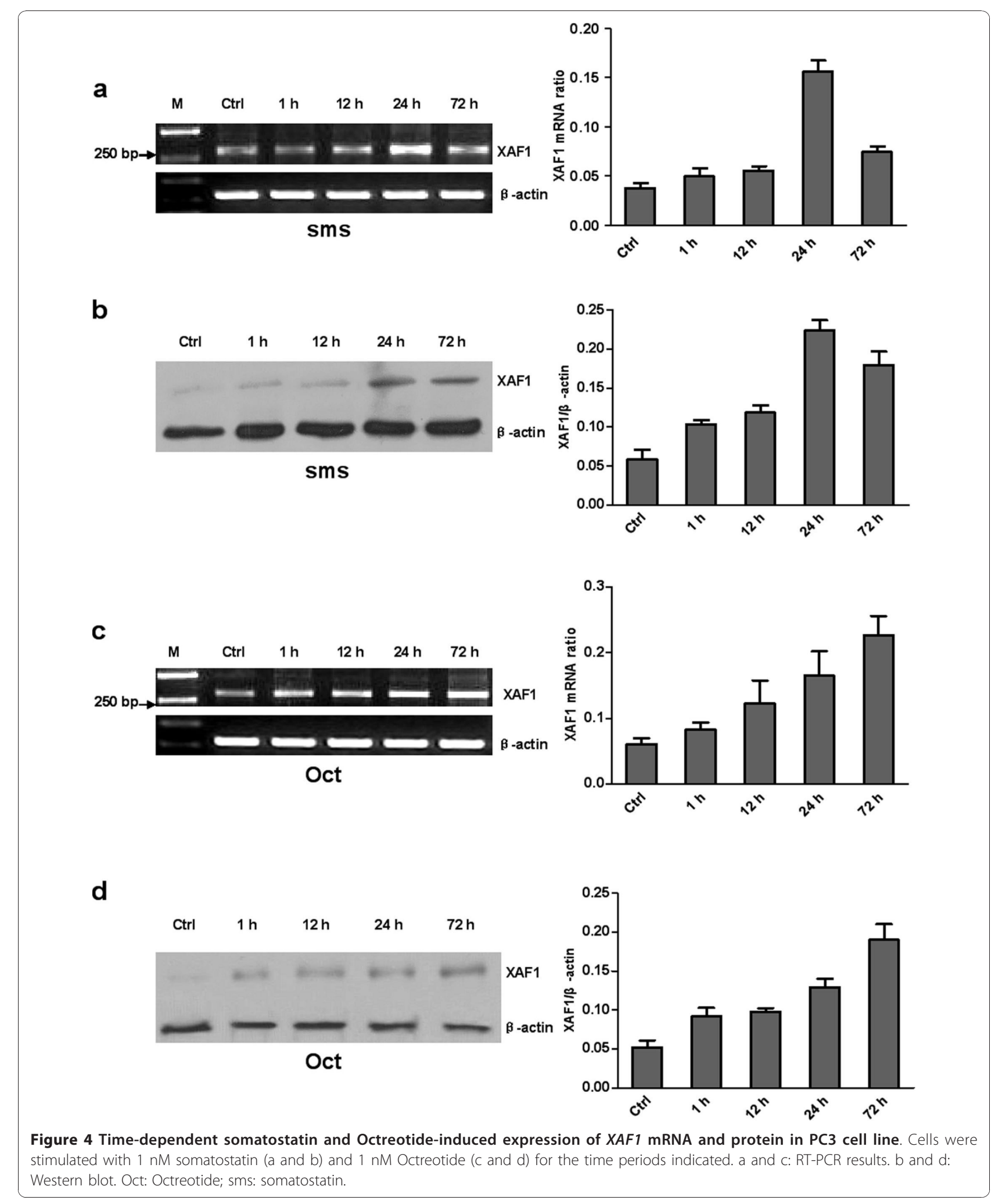


cells that express endogenous SSTR2 [36] and in human pancreatic cancer cells expressing mutated $p 53$ and devoid of endogenous SSTR2, after correction of the deficiency by expression of SSTR2 [37]. Thus, somatostatin can induce apoptosis by $p 53$-dependent and -independent mechanisms. SSTR2 induces apoptosis in a tyrosine phosphatase SHP-1-dependent manner.

Currently, several somatostatin analogues including Octreotide, Lanreotide, Vapreotide, Seglitide and so on, are available for the treatment of several kinds of disorders. Octreotide was the first developed analogue and is widely used for symptomatic treatment of hormone secreting neuroendocrine tumours. It has higher affinity for SSTR2 and shows significant anti-neoplastic actions in tumours expressing SSTR2 [38]. It remains the drug of choice for application in a majority of pure NE tumours because such tumours predominantly express SSTR2 [39]. However, other somatostatin analogues such as Lanreotide, which have good affinity for SSTR5 in addition to that for SSTR2, may advantageously recognize SSTR5 expressing tumours. But the relationship between XAF1 and somatostatin receptors needs further elucidation.

In our previous studies [24], we found that somatostatin up-regulated the expression of SSTR1-5, and that apoptosis was activated mainly via the induced expressions of SSTR2 and SSTR3. The effects of somatostatin on the prostate cancer cells may be mediated by enhanced expression of $X A F 1$ through its pro-apoptotic effect. Somatostatin and Octreotide up-regulate XAF1 mRNA and protein in all prostate cancer cell lines, but the underlying mechanisms need further investigations. Likely, up-regulation of $X A F 1$ mediated by somatostatin and Octreotide triggers cancer cell apoptosis.

\section{Conclusions}

To our knowledge, little is known about the regulatory effects of XAF1 in many different types of human cancers. We report, the first time, that somatostatin and Octreotide up-regulate XAF1 mRNA and protein expression in LNCaP, DU145 and PC3 prostate cancer cell lines. Our findings suggest that $X A F 1$ down-regulation may contribute to the prostate cancer development. The enhanced XAF1 expression by somatostatin indicates a promising strategy for prostate cancer therapy.

\section{Abbreviations List}

NE: neuroendocrine; RWPE-1: human prostate epithelial cell line; SSTR: somatostatin receptor; XAF1: X-linked inhibitor of apoptosis proteinassociated factor-1; XIAP: X-linked inhibitor of apoptosis.

\section{Acknowledgements}

This work was supported by the National Natural Science Foundation of China (No. 30772294) and Shandong Natural Science Foundation (No. ZR2010HM026).

\section{Author details}

'Department of Integrated Traditional Chinese and Western Medicine, Qilu Hospital, Shandong University, Jinan, 250012 P.R. China. ²Department of Urology, Qilu Hospital, Shandong University, Jinan, 250012 P.R. China.

${ }^{3}$ Ageing Center, School of Nursing, Shandong University, Jinan, 250012 P.R. China. ${ }^{4}$ Department of Pathology \& Oncology, Karolinska Institutet, 17176 Stockholm, Sweden.

\section{Authors' contributions}

ZQX and ZLZ carried out experimental procedures and drafted manuscript. RY participated in its design. CDL and SN revised it critically. SLL and ZXL guaranteed the whole study. All authors read and approved the final manuscript.

\section{Competing interests}

The authors declare that they have no competing interests.

Received: 3 November 2010 Accepted: 11 December 2010

Published: 11 December 2010

\section{References}

1. Jemal A, Siegel R, Ward E, Hao Y, Xu J, Murray T, Thun MJ: Cancer statistics, 2008. CA Cancer J Clin 2008, 58:71-96.

2. Boyle P, Ferlay J: Cancer incidence and mortality in Europe, 2004. Ann Oncol 2005, 16:481-488.

3. Quinn M, Babb P: Patterns and trends in prostate cancer incidence, survival, prevalence and mortality. Part I: international comparisons. BJU Int 2002, 90:162-173.

4. Ostrander EA, Stanford JL: Genetics of prostate cancer: too many loci, too few genes. Am J Hum Gnent 2000, 67:1367-1375.

5. Foley R, Hollywood D, Lawler M: Molecular pathology of prostate cancer: the key to identifying new biomarkers of disease. Endocr Relat Cancer 2004, 11:477-488.

6. Wang G, Reed E, Li QQ: Apoptosis in prostate cancer: progressive and therapeutic implications (Review). Int J Mol Med 2004, 14:23-34.

7. Zeng $L$, Kyprianou N: Apoptotic regulators in prostatic intraepithelial neoplasia (PIN): value in prostate cancer detection and prevention. Prostate Cancer Prostatic Dis 2005, 8:7-13.

8. Liston P, Fong WG, Kelly NL, Toji S, Miyazaki T, Conte D, Tamai K, Craig CG, McBurney MW, Korneluk RG: Identification of XAF1 as an antagonist of XIAP anti-Caspase activity. Nat Cell Biol 2001, 3:128-133.

9. Jang JH, Bengali Z, Houchin TL, Shea LD: Surface adsorption of DNA to tissue engineering scaffolds for efficient gene delivery. J Biomed Mater Res 2006, 77:50-58

10. Leaman DW, Chawla-Sarkar M, Vyas K, Reheman M, Tamai K, Toji S, Borden EC: Identification of X-linked inhibitor of apoptosis-associated factor-1 as an interferon-stimulated gene that augments TRAIL Apo2Linduced apoptosis. J Biol Chem 2002, 277:28504-28511.

11. Chung SK, Lee MG, Ryu BK, Lee JH, Han J, Byun DS, Chae KS, Lee KY, Jang JY, Kim HJ, Chi SG: Frequent alteration of XAF1 in human colorectal cancers: implication for tumor cell resistance to apoptotic stresses. Gastroenterology 2007, 132:2459-2477.

12. Xia Y, Novak R, Lewis J, Duckett CS, Phillips AC: Xaf1 can cooperate with TNFalpha in the induction of apoptosis, independently of interaction with XIAP. Mol Cell Biochem 2006, 286:67-76.

13. Fong WG, Liston P, Rajcan-Separovic E, St Jean M, Craig C, Korneluk RG: Expression and genetic analysis of XIAP-associated factor 1 (XAF1) in cancer cell lines. Genomics 2000, 70:113-122.

14. Ng KC, Campos El, Martinka M, Li G: XAF1 expression is significantly reduced in human melanoma. J Invest Dermatol 2004, 123:1127-1134

15. Lee MG, Huh JS, Chung SK, Lee JH, Byun DS, Ryu BK, Kang MJ, Chae KS, Lee SJ, Lee CH, Kim Jl, Chang SG, Chi SG: Promoter CpG hypermethylation and downregulation of XAF1 expression in human urogenital malignancies: implication for attenuated $\mathrm{p} 53$ response to apoptotic stresses. Oncogene 2006, 25:5807-5822. 
16. Byun DS, Cho K, Ryu BK, Lee MG, Kang MJ, Kim HR, Chi SG: Hypermethylation of XIAP-associated factor 1 , a putative tumor suppressor gene from the 17p13.2 locus, in human gastric adenocarcinomas. Cancer Res 2003, 63:7068-7075.

17. Joensuu TK, Nilsson S, Holmberg AR, Marquez M, Tenhunen M, Saarto T, Joensuu H: Phase I trial on sms-D70 somatostatin analogue in advanced prostate and renal cell cancer. Ann N Y Acad Sci 2004, 1028:361-374.

18. Liu Y: Radiolabelled somatostatin analog therapy in prostate cancer: current status and future directions. Cancer Lett 2006, 239:21-26.

19. Moller LN, Stidsen CE, Hartmann B, Holst JJ: Somatostatin receptors. Biochim Biophys Acta 2003, 1616:1-84.

20. Olias G, Viollet C, Kusserow H, Epelbaum J, Meyerhof W: Regulation and function of somatostatin receptors. J Neurochem 2004, 89:1057-1091.

21. Tatoud R, Degeorges A, Prevost G, Hoepffner JL, Gauville C, Millot G, Thomas F, Calvo F: Somatostatin receptors in prostate tissues and derived cell cultures, and the in vitro growth inhibitory effect of BIM23014 analog. Mol Cell Endocrinol 1995, 113:195-204.

22. Kvols LK, Moertel CG, O'Connell MJ, Schutt AJ, Rubin J, Hahn RG: Treatment of the malignant carcinoid syndrome. Evaluation of a long-acting somatostatin analogue. N Engl J Med 1986, 315:663-666.

23. Liu Z, Marquez M, Nilsson S, Holmberg AR: Comparison of protein expression in two prostate cancer cell-lines, LNCaP and DU145, after treatment with somatostatin. Oncol Rep 2009, 22:1451-1458.

24. Liu Z, Marquez M, Nilsson S, Holmberg AR: Incubation with somatostatin, 5 -aza decitabine and trichostatin up-regulates somatostatin receptor expression in prostate cancer cells. Oncol Rep 2008, 20:151-154.

25. Brevini TA, Bianchi R, Motta M: Direct inhibitory effect of somatostatin on the growth of the human prostatic cancer cell line LNCaP: possible mechanism of action. J Clin Endocrinol Metab 1993, 77:626-631.

26. Straszewski-Chavez SL, Visintin IP, Karassina N, Los G, Liston P, Halaban R, Fadiel A, Mor G: XAF1 mediates tumor necrosis factor-alpha-induced apoptosis and $\mathrm{X}$-linked inhibitor of apoptosis cleavage by acting through the mitochondrial pathway. J Biol Chem 2007, 282:13059-13072.

27. Micali OC, Cheung HH, Plenchette S, Hurley SL, Liston P, LaCasse EC, Korneluk RG: Silencing of the XAF1 gene by promoter hypermethylation in cancer cells and reactivation to TRAIL-sensitization by IFN-beta. BMC Cancer 2007, 7:52.

28. Sun Y, Qiao L, Xia HH, Lin MC, Zou B, Yuan Y, Zhu S, Gu Q, Cheung TK, Kung HF, Yuen MF, Chan AO, Wong BC: Regulation of XAF1 expression in human colon cancer cell by interferon beta: activation by the transcription regulator STAT1. Cancer Lett 2008, 260:62-71.

29. Yu LF, Wang J, Zou B, Lin MC, Wu YL, Xia HH, Sun YW, Gu Q, He H, Lam SK, Kung HF, Wong BC: XAF1 mediates apoptosis through an extracellular signal-regulated kinase pathway in colon cancer. Cancer 2007, 109:1996-2003.

30. Tu SP, Liston P, Cui JT, Lin MC, Jiang XH, Yang Y, Gu Q, Jiang SH, Lum CT, Kung HF, Korneluk RG, Wong BC: Restoration of XAF1 expression induces apoptosis and inhibits tumor growth in gastric cancer. Int J Cancer 2009, 125:688-697.

31. Ma TL, Ni PH, Zhong J, Tan JH, Qiao MM, Jiang SH: Low expression of XIAP-associated factor 1 in human colorectal cancers. Chin J Dig Dis 2005, 6:10-14.

32. Ferreira CG, van der Valk P, Span SW, Ludwig I, Smit EF, Kruyt FA, Pinedo HM, van Tinteren H, Giaccone G: Expression of X-linked inhibitor of apoptosis as a novel prognostic marker in radically resected nonsmall cell lung cancer patients. Clin Cancer Res 2001, 7:2468-2474.

33. Secchiero P, di lasio MG, Melloni E, Vlotan R, Celeghini C, Tiribelli M, Dal Bo M, Gattei V, Zauli G: The expression levels of the pro-apoptotic XAF-1 gene modulate the cytotoxic response to Nutlin-3 in B chronic lymphocytic leukemia. Leukemia 2010, 24:480-483.

34. Liu D, Martino G, Thangaraju M, Sharma M, Halwani F, Shen SH, Patel YC, Srikant CB: Caspase-8-mediated intracellular acidification precedes mitochondrial dysfunction in somatostatin-induced apoptosis. J Biol Chem 2000, 275:9244-9250.

35. Sharma K, Srikant CB: Induction of wild-type p53, Bax, and acidic endonuclease during somatostatin-signaled apoptosis in MCF-7 human breast cancer cells. Int J Cancer 1998, 76:259-266.

36. Maradona JA, Carton JA, Asensi V, Rodriguez-Guardado A: AIDS-related Kaposi's sarcoma with chylothorax and pericardial involvement satisfactorily treated with liposomal doxorubicin. AIDS (London, England) 2002, 16:806.
37. Guillermet J, Saint-Laurent N, Rochaix P, Cuvillier O, Levade T, Schally AV, Pradayrol $L$, Buscail $L$, Susini $C$, Bousquet $C$ : Somatostatin receptor subtype 2 sensitizes human pancreatic cancer cells to death ligand-induced apoptosis. Proc Natl Acad Sci USA 2003, 100:155-160.

38. Reubi JC, Schar JC, Waser B, Wenger S, Heppeler A, Schmitt JS, Macke HR: Affinity profiles for human somatostatin receptor subtypes SST1-SST5 of somatostatin radiotracers selected for scintigraphic and radiotherapeutic use. Eur J Nucl Med 2000, 27:273-282.

39. Reubi JC, Waser B, Schaer JC, Laissue JA: Somatostatin receptor sst1-sst5 expression in normal and neoplastic human tissues using receptor autoradiography with subtype-selective ligands. Eur J NuCl Med 2001, 28:836-846.

doi:10.1186/1756-9966-29-162

Cite this article as: Xing et al:: XAF1 expression and regulatory effects of somatostatin on XAF1 in prostate cancer cells. Journal of Experimental \& Clinical Cancer Research 2010 29:162.

\section{Submit your next manuscript to BioMed Central and take full advantage of:}

- Convenient online submission

- Thorough peer review

- No space constraints or color figure charges

- Immediate publication on acceptance

- Inclusion in PubMed, CAS, Scopus and Google Scholar

- Research which is freely available for redistribution

Submit your manuscript at www.biomedcentral.com/submit
Ciomed Central 